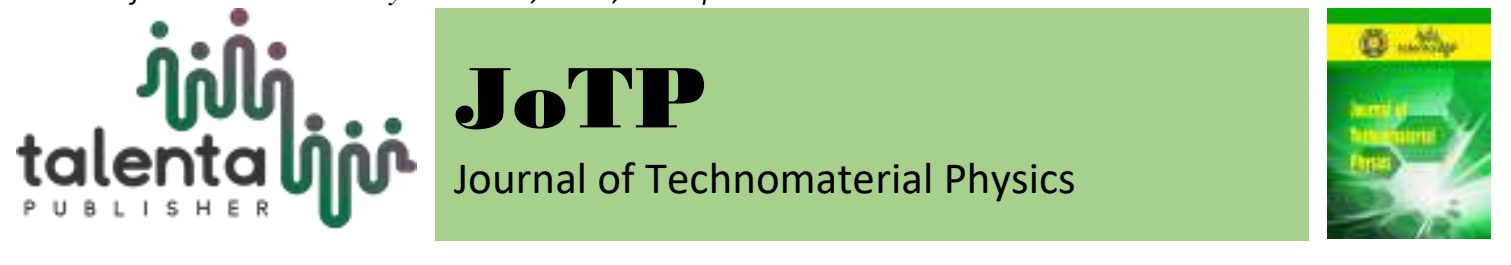

\title{
Solar Power-Based Thermo Electric Cooler (TEC) System
}

\author{
Marhaposan Situmorang $^{1}$ and Monika Panjaitan $^{2}$ \\ ${ }^{1,2}$ Department of Physics, Faculty of Mathematics and Natural Sciences, Universitas Sumatera Utara, Jl. \\ Bioteknologi No. 1 Kampus USU, Medan, Indonesia, 20155
}

\begin{abstract}
Solar energy has been considered as a promising renewable energy source for electric power generation. Solar panel systems have become a popular object to be developed by researchers, but the low efficiency of solar panels in energy conversion is one of the weaknesses of this system. Factors that affect the output produced by solar panels are the intensity of sunlight and the working temperature of the solar panels. The solar panel module has a single operating point where the voltage and current outputs produce the maximum power output. There are three main methods in Maximum Power Point Tracking (MPPT), namely conventional methods, artificial intelligence methods, and hybrid methods. In most solar panel systems, this study uses Maximum Power Point Tracking (MPPT) with perturb and observe algorithms to maximize the use of solar energy. The maximum power point extracted by MPPT will be supplied to the battery and controlled by the Charge Controller. The energy stored in the battery will be used by the Thermo Electric Cooler cooling system to reach the desired temperature point using the keypad as temperature input.
\end{abstract}

Keyword: Solar Panel, Maximum Power Point Tracking (MPPT), Thermo Electric Cooler.

Received 19 August 2021 | Revised [ 23 August 2021] | Accepted [27 August 2021]

\section{Introduction}

Electrical energy is a very important need in everyday life, the increasing demand for electrical energy every year requires the provider to be responsive in solving any energy problems that occur [1]. One of the problems regarding electrical energy is the availability of fossil energy sources as fuel for generation which decreases every year, this makes the development of new and renewable alternative energy sources a focus in this era [2]. Renewable energy is energy whose primary material sources can be easily taken, can be renewed and reused. One example of renewable energy is solar energy [3].

Utilization of solar energy is very important at this time which is converted into electrical energy by using solar panels which function as the main equipment of the power generation system. In conventional applications, solar panels have many shortcomings, especially in terms

\footnotetext{
*Corresponding author at: Jalan Biolteknologi no.1 Medan, 20155, Indonesia

E-mail address: marhaposan@usu.ac.id
} 
of low output efficiency, this is due to the different characteristics between solar panels and loads [4]. In addition, there are several factors that affect the electrical power generated by solar panels, such as the amount of light intensity and the working temperature of the solar panels. Therefore we need a technology that can maximize the output power of the solar panels [5]. In order to maximize the power generated by the PV system, the following techniques are applied maximum power point tracking (MPPT) [6]. Various control algorithms are sought to maximize the power of the PV system. In this study, the use of the method was studied perturb and observe $(\mathrm{P} \& \mathrm{O})$ which is implemented on pulse width modulation (pulse-width modulation/PWM) to control boost converter [7]. A solar panel is a component that can be used to convert sunlight energy into electrical energy using a principle called the photovoltaic effect [8]. The electrical energy produced is usually used for electricity needs and some is stored in advance with batteries. The workings of this solar-powered panel system can still run even in the afternoon, evening or even in the rain because it uses the help of the battery. Sunlight that shines on the earth can be converted into electrical energy through a process called photovoltaic (PV) [9].

Photovoltaic cells are made of semiconductor materials, especially silicon which is coated by a special additive. If sunlight reaches the cell, the electrons will be released from the silicon atoms and flow to form an electrical circuit so that electrical energy can be generated. Solar cells are always designed to convert light into as much electrical energy as possible and can be combined in series or parallel to produce the desired voltage and current [10]. Maximum Power Point Tracking or often abbreviated as MPPT is an electronic system that is operated on a photovoltaic (PV) panel so that the photovoltaic panel can produce maximum power [11]. It should be noted that MPPT is not a mechanical tracking system that is used to change the position of the module to the position of the sun so that it gets the maximum solar energy. MPPT is really an electronic system that can track the maximum power point of power that can be issued by a PV panel [12] Based on the above reference, a research was conducted on a solar-based Thermo Electric Cooler (TEC) cooling system.

\section{Methods}

\subsection{Block Diagram}

In the research process, tool making and tool testing are carried out at the Basic Electronics Laboratory, the research process, from tool making, tool testing and data processing. The System Block Diagram presented in the figure below shows the main parts of the system as well as inputs and outputs. System input is electrical energy sourced from solar panels [13]. MPPT tracks the maximum power on the solar panels. Charge Controller manages charging from MPPT to Battery. The battery stores the generated power [14]. The system output is temperature. The initial temperature is set by the keypad. The microcontroller executes 
commands to calculate temperature changes that occur in the test room, the resulting data will be stored via the SD Card Module [15]. The battery provides an electric current to TEC1 12706, causing hot temperatures on the heat dissipation side and cold temperatures on the test chamber side. The LCD will display the temperature change from the DS18B20 sensor [16]. Heat is removed using a pump when the value is $\mathrm{ON}$, the pump flows water continuously so that heat can be wasted into the water as a heat sink, waterblock as a heatsink on the water as a heat sink [17].

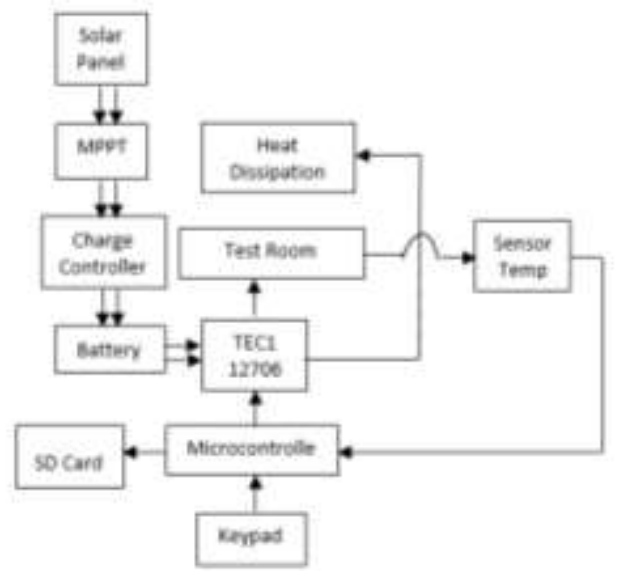

Figure 1. Block Diagram of the system

\subsection{Flowchart}

The flowchart of the system is given in in Figure 2.

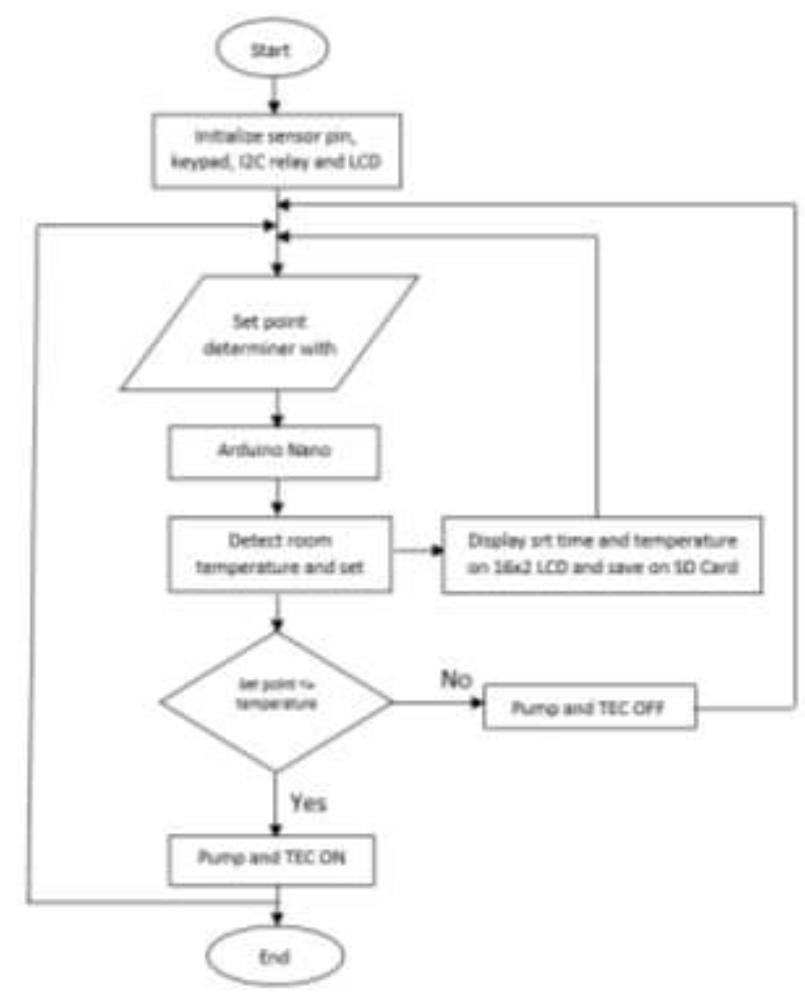

Figure 2. Flowchart of the system 


\section{Result and Discussion}

\subsection{Testing the Solar Panel Characteristics Curve}

Testing the characteristics of solar panels is carried out to see the value of the output voltage and current generated by the solar panels. The following are the results of tests carried out using different loads and different intensities.

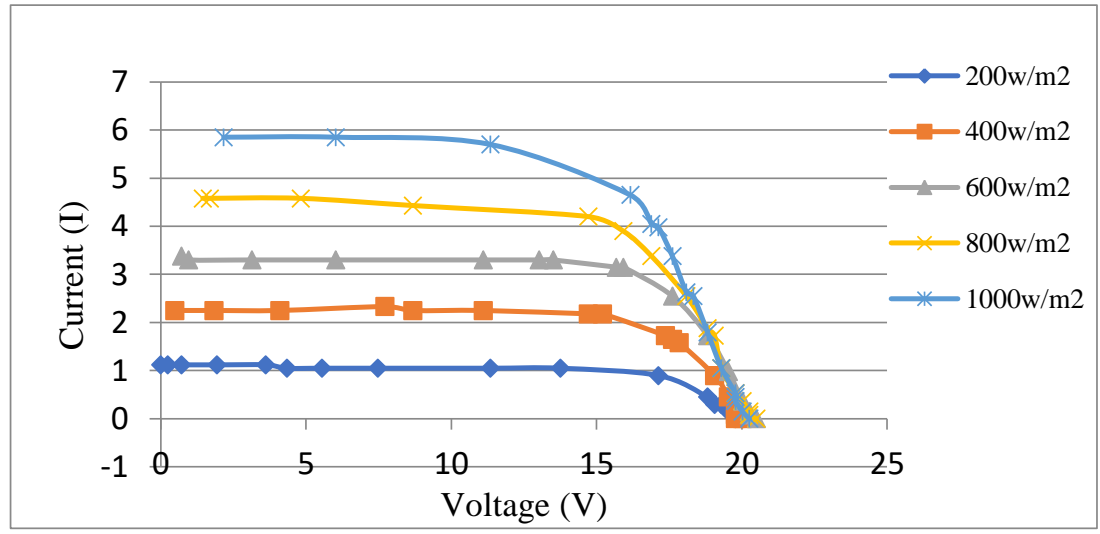

Figure 3. Current and Voltage characteristic curve

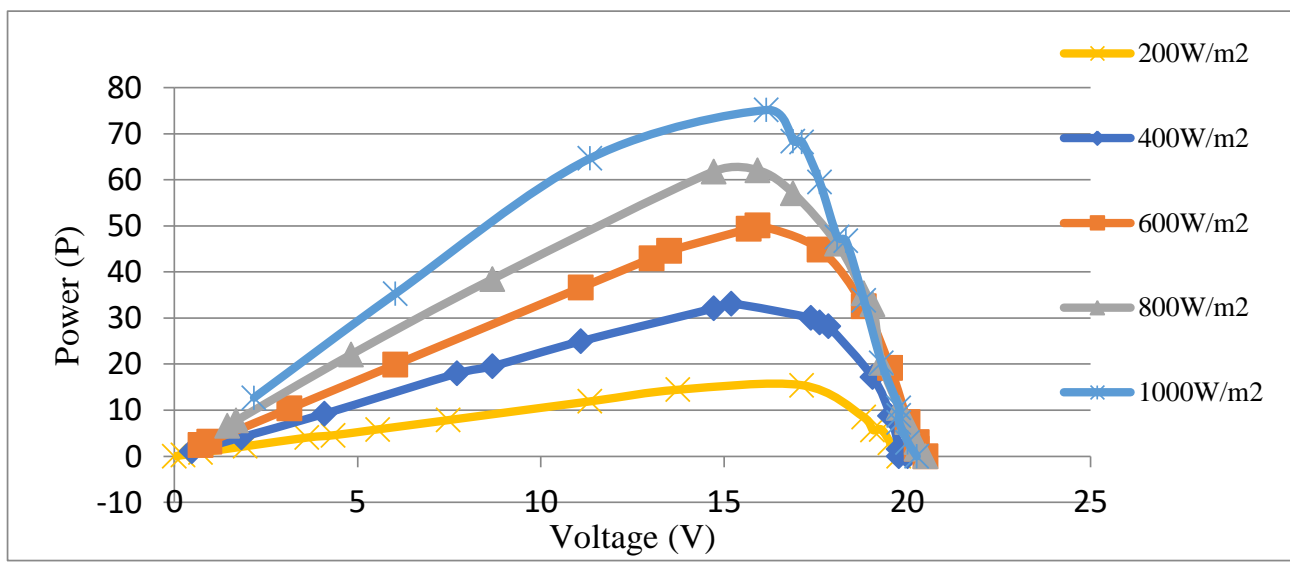

Figure 4. Power vs Voltage characteristic curve

In Figure 3 and Figure 4 above, are the characteristic curves of the solar panel test results using different loads, namely: $0.33 \Omega, 0.39 \Omega, 1 \Omega, 1.8 \Omega, 3.3 \Omega, 3.9 \Omega, 4.7 \Omega, 6.8 \Omega, 10 \Omega, 12 \Omega, 18$ $\Omega, 39 \Omega, 56 \Omega, 120 \Omega, 150 \Omega$, and $220 \Omega$. And also the test is carried out by adjusting the light intensity of $200 \mathrm{~W} / \mathrm{m}^{2}, 400 \mathrm{~W} / \mathrm{m}^{2}, 600 \mathrm{~W} / \mathrm{m}^{2}, 800 \mathrm{~W} / \mathrm{m}^{2}$ dan $1000 \mathrm{~W} / \mathrm{m}^{2}$. Then the data obtained in the form of a graph between Current vs Voltage and Power vs Voltage. Where the maximum power obtained from the curve is 75,144 watt.

\subsection{Solar Panel Efficiency}

Solar panel efficiency is the ratio between the output power and the input power, where the output power is the product of the voltage and current, while the input is the product of the surface area and the intensity. So, from the data that has been obtained, it can be concluded that:

$$
\eta=\frac{P \max }{I x A} \times 100 \%
$$


$I$ (intensity) $\quad: 1000 \mathrm{watt} / \mathrm{m}^{2}$

A $\quad: 0.125 \mathrm{~m} \times 0.125 \mathrm{~m} \times 36=0.5625 \mathrm{~m}^{2}$

average $\mathrm{P}_{\text {out }} \quad: 75,144 \mathrm{~W}$

Then the efficiency value of the solar panel is:

$$
\begin{aligned}
& \eta=\frac{\text { Average Pout }}{I x A} \times 100 \% \\
& \eta=\frac{75,144}{1000 \times 0,5625} \times 100 \% \\
& \eta=13,35 \%
\end{aligned}
$$

\subsection{PT P\&O efficiency}

From the data generated using MPPT P\&O, the average value of the input voltage is $17.65 \mathrm{~V}$, the average value of the output voltage is $18.75 \mathrm{~V}$, the average value of the input current is 3.08 $\mathrm{A}$, the average value of the output current is of $2.48 \mathrm{~A}$. Then the average value of the input power is $54.36 \mathrm{~W}$ and the average value of the output power is $46.5 \mathrm{~W}$.

So that the value of efficiency is obtained:

$$
\begin{aligned}
& \eta=\frac{\text { Pout }}{\text { Pin }} \times 100 \% \\
& \eta=\frac{46,5}{54,36} \times 100 \% \\
& \eta=85,53 \%
\end{aligned}
$$

Then the power efficiency using MPPT is $85,53 \%$.

\subsection{Thermoelectric Performance Coefficient}

In this study, TEC1-12706 was used with the following spacification based on the data sheet:

$\begin{array}{ll}\text { Working Voltage } & : 0-15,2 \mathrm{~V} \mathrm{DC} \\ \text { Working Current } & : 6 \text { Ampere } \\ \text { Pmax } & : 91,2 \mathrm{Watt} \\ \text { Dimension } & : 4 \mathrm{~cm} \mathrm{x} 4 \mathrm{~cm} \mathrm{x} 4 \mathrm{~cm} \\ \text { Weight } & : 25 \mathrm{~g}\end{array}$

When the TEC is powered by a voltage of $12 \mathrm{~V}$ and a current of $5 \mathrm{~A}$ it will have a temperature difference between 5 on the cold side to $200{ }^{\circ} \mathrm{C}$ on the hot side, this can cause damage if the heat of the tool is not disposed of properly, therefore the tool used uses a pump to running water continuously as a heat dissipator and a waterblock as an equivalent which is connected to the cold side of the test chamber and the hot side of the water storage block [18]-[20]. 


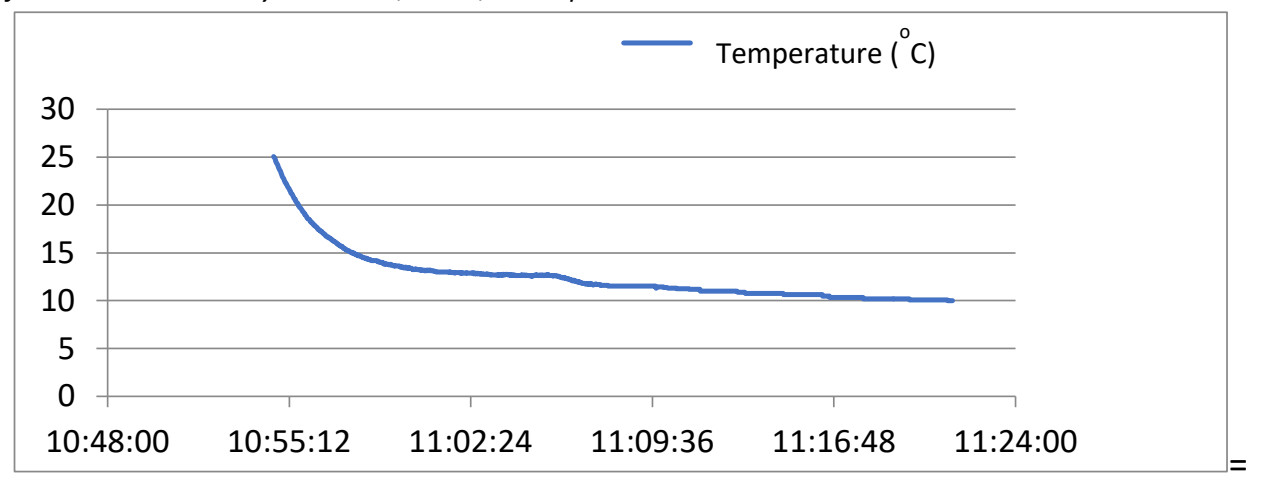

Fig 5. Graph of Temperature Drop

The graph above shows the process of decreasing the temperature in the test room with room dimensions of $0.2 \mathrm{~m} \times 0.2 \mathrm{~m} \times 0.2 \mathrm{~m}\left(0,008 \mathrm{~m}^{3}\right)$ with the initial temperature set at $10^{\circ} \mathrm{C}$. The heat absorbed by the cold side:

$$
\begin{aligned}
& \mathrm{Q}_{\mathrm{L}}=\left[S I T_{C}-\frac{1}{2} I^{2} R-K\left(T_{H} T_{C}\right)\right] \\
& \mathrm{Q}_{\mathrm{L}}=-3,77 \mathrm{~J}
\end{aligned}
$$

Heat absorbed by the hot side:

$$
\begin{aligned}
& \mathrm{Q}_{\mathrm{H}}=\left[S I T_{H}+\frac{1}{2} I^{2} R-K\left(T_{H}-T_{C}\right)\right] \\
& \mathrm{Q}_{\mathrm{H}}=12,59 \mathrm{~J}
\end{aligned}
$$

Total Energy Supplied:

$$
\begin{aligned}
& \mathrm{W}=\mathrm{Q}_{\mathrm{H}}-\mathrm{Q}_{\mathrm{L}} \\
& \mathrm{W}=12,59-(-3,77)=16,37 \mathrm{~J}
\end{aligned}
$$

COP calculation:

$$
\begin{aligned}
& \mathrm{COP}=\mathrm{Q}_{\mathrm{C}} / \text { Total Energi }(\mathrm{W}) \\
& \mathrm{COP}=\frac{3,77}{16,37}=0,2307 \\
& \eta_{\mathrm{COP}}=23,07 \%
\end{aligned}
$$

\subsection{Overall Efficiency Performance of Power-Based System Solar Panel}

Based on all the data that has been obtained, we can calculate the overall performance efficiency of the system by calculating the solar panel efficiency, mppt efficiency, and the coefficient of Thermoelectric Performance as follows: [12]

$$
\begin{aligned}
\eta_{\text {SYSTEM }} & =\eta_{P V} \times \eta_{M P P T} \times \eta_{C O P} \times 100 \% \\
& =13,35 \% \times 85,53 \% \times 23,07 \% \times 100 \% \\
& =\frac{13,35}{100} \times \frac{85,53}{100} \times \frac{23,07}{100} \times 100 \% \\
& =0.1335 \times 0,8553 \times 0,2307 \times 100 \% \\
& =2,63 \%
\end{aligned}
$$




\section{Conclusion}

From the results of research conducted, the efficiency value of the solar panels used is $13.35 \%$. The efficiency of solar panels is low which is caused by the reflection of light back into the air and is influenced by the intensity of sunlight. The value of the efficiency of the MPPT system tool is $85.53 \%$. The MPPT efficiency value from this study can track the optimum power from the solar panel output. TEC cooling system coefficient value is $23.07 \%$. The TEC coefficient value is relatively low due to the power supplied to the TEC cooling system is partly wasted on the side of the hot room. And the entire power supply system with an efficiency of $2.63 \%$. From the results of research conducted, the lowest temperature point value obtained from the Thermo Electric Cooler (TEC) cooling system is $10{ }^{\circ} \mathrm{C}$ from the initial room temperature of $25.06{ }^{\circ} \mathrm{C}$. And the time it takes to reach that temperature point is 26 minutes 55 seconds.

\section{REFERENCES}

[1] M. A. Greeen, Solar Cells Opertaing Principles, Technology and System Applications, New Jersey: Prentice-Hall, 1982.

[2] M. Ikbal, Interkoneksi Sistem Photovoltaic dengan Grid", Bandung: Program studi teknik elektro ITB, 2008.

[3] S. Nema, R. K. Nema, and G. Agnihotri, "Matlab Simulink Based Study of Photovoltaic Cells Modules Array and Their Experimental Verification," International Journal of Energy and Environment, 1 (3), 487-500, 2010.

[4] W. Xiao, W. G. Dunford, P. R. Palmer, and A. Capel, "Regulation of Photovoltaic Voltage," Industrial Electronics, IEEE Transaction, 54(3), 1365-1374, 2007.

[5] A. Rafi, and M. Rif'an, Perancangan Sistem Penjejak Matahari Berbasis Mikrocontroller dan Sensor Cahaya, Skripsi, 2007.

[6] P. Rudito., Pengaturan PWM (Pulse Width Modulation) dengan PLC, Universitas Brawijaya, 2012.

[7] D. Yacine, G. Jean-Paul, R. Lazhar, Implementation of a new maximum powerd point tracking control strategy for small wind energi conversion systems without mechanical sensors, Energi Conversion and Management, 2015.

[8] B. Abdellahi., Performance Optimization of the PV Pumping System, Abdelmalek Essaadi University, Marocco, 2018.

[9] T. S. Haruno, Pompa dan Kompresor, Jakarta: Pradnya Paramita, 2000.

[10] L. Plegari and R. Rizzo, Adaptive perturb and observe algorithm for photovoltaic maximum power point tracking, Renewable Power, 2010.

[11] D. W. Hart, Introduction to Power Electronics, New Jersey: Prentics-Hall, 1997.

[12] N. Lavanya, R.E Ravalika and V. Dharani., Design and Fabrication of a Portable Refrigerator Based on Peltier Effect, India: GPREC, 2018.

[13] Goodwin, G. Clifford, S. F. Graebe and M. E. Salgado, Control System Design. vol. 240. New Jersey: Prentice Hall, 2001.

[14] M. Astra, Studi rancang bangun Solar Charge Controller dengan indikator arus, tegangan dan suhu berbasis mikrokontroler ATMEGA 8535, Jakarta: Universitas Negeri Jakarta, 2011.

[15] B. Dokic, Power Electronics Converters And Regulators Third Edition, New York: Springer International Publishing Switzerland, 2015.

[16] I. Winarni, Maximum Power Point Tracker (MPPT) berdasarkan metode perturb and observe dengan system tracking panel surya single axis, Surabaya: Universitas Hang Tuah, 
2017.

[17] G. Wibisono, MPPT menggunakan metode Hibrid JST dan Algoritma Genetika untuk sistem Photovoltaic, Universitas Negeri Jakarta, 2014.

[18] W. A. Salah, S. Taib and A. Al-Mofleh. "Development of Multistage Converter for Outdoor Thermal Electric Cooling (TEC) Applications." JJMIE, vol. 4. no. 1, 2010.

[19] W. A. Salah, S. Taib, A. Al-Mofleh and H. A. Ghulman, "Solar Powered Air Conditioning by Aid of TEC for Mina Tents Application," 2013.

[20] Kinage, Arpit, S. Sahoo and S. Chaudhuri, "Effects of different electrical arrangements and Thomson effect on the system performance as well as the optimum allocation of thermocouples in a self-driven two-stage TEC \& TEG." Thermal Science and Engineering Progress, vol. 101035, 2021. 